\title{
Biodiversity and Abundance of Phytoplankton from Muthupettai Mangrove Region, South East Coast of India
}

\author{
Varadharajan $D^{*}$ and Soundarapandian $\mathbf{P}$ \\ Faculty of Marine Science, Centre of Advanced Study in Marine Biology, Annamalai University, Parangipettai-608 502, Tamil Nadu, India
}

\begin{abstract}
Phytoplanktons are of great ecological worth since they comprise the major portion of primary producers in the marine environment. In the present study, a total of 95 species of phytoplankton were recorded from both the stations, of which, station I recorded 87 species and station II recorded 76 species. The phytoplankton species are maximum were observed in station I and minimum were observed station II. The phytoplankton recorded with the present study was belongings to families Coscinodisceae (17) > Ceratiaceae (12) > Chaetoceraceae (11) > Biddulphoidae (9) > Naviculaceae $(9)>$ Triceratiinae $(6)>$ Solenoidae (6) $>$ Fragilariaceae (5) $>$ Dinophyceae $(5)>$ Cyanophyceae $(4)$ $>$ Euodicidae (3) > Eucambiinae (2) > Prorocentraceae (2) > Triadiniaceae (2) > Isthiminae (1) > Gonyaulacaceae (1). The percentage contribution of phytoplankton families at two different station was in a decrease order as given below: Coscinodisceae $(17.89 \%)>$ Ceratiaceae $(12.63 \%)>$ Chaetoceraceae $(11.57 \%)>$ Biddulphoidae $(9.47 \%)$ $>$ Naviculaceae $(9.47 \%)>$ Triceratiinae $(6.31 \%)>$ Solenoidae $(6.31 \%)>$ Fragilariaceae $(5.26 \%)>$ Dinophyceae $(5.26 \%)>$ Cyanophyceae $(4.21 \%)>$ Euodicidae $(3.15 \%)>$ Eucambiinae $(2.10 \%)>$ Prorocentraceae $(2.10 \%)>$ Triadiniaceae $(2.10 \%)>$ Isthiminae $(1.05 \%)>$ Gonyaulacaceae $(1.05 \%)$. The data analysis in Margalef's species richness $\left(d^{\prime}\right)$, Shannon-Weiner diversity function $\left(H^{\prime}\right)$, Pielou's evenness $\left(J^{\prime}\right)$ and Simpson's dominance $\left(1-\lambda^{\prime}\right)$ was used to reflect the underlying changes in physical and chemical properties of phytoplankton species. The species richness and diversity of phytoplankton at three sampling stations were determined using Pielous evenness were highest at the station I (0.9215) and lowest at the station II (0.8340). Both Margalef's diversity and richness were highest at the stations 1 (4.2157 and 5.3810) and lowest at the station II (4.1452 and 5.1073). Both Shannon and Simpson indices were highest at the stations I (4.3261 and 0.9175) and lowest at the station II (4.2958 and 0.9051).
\end{abstract}

Keywords: Phytoplankton; Species; Abundance; Seasons; Mangrove region

\section{Introduction}

Phytoplanktons are photosynthesizing microscopic plant-like organisms that inhabit the upper sunlit layer of almost all oceans and bodies of fresh water. There are over 40,000 different spices of marine phytoplankton and they are microscopic, single-celled, organisms that live in our oceans. The phytoplankton species are predominantly autotrophic or holophytic organisms. More than 10,000 living diatom species are known, there are over 8,000 species of Algae, there are 1500 species of Blue Green algae or Cyanobacteria, there are 6000 species of red algae or Rhodophyta [1-4]. The occurrence of phytoplankton in any aquatic system is biological wealth of water for tiny zooplankton to large marine mammals, seabirds and fish and constitutes a vital link in the food chain and support the economically important fish population [5]. They are tiny organisms with the ability to convert sunlight, warmth, water and minerals into edible nutrients like protein, carbohydrates, vitamins and amino acids [6,7]. However the plankton is considered a potential source of human food and also responsible for creating the majority of the world's oxygen and diet that is supplemented with marine phytoplankton encourages optimal liver function, stabilizes blood sugar levels and helps relieve joint pain, stiffness, thyroid, reduce cholesterol levels and a key factor in cardiovascular and heart disease. The biodiversity of phytoplankton is very high, but people still do not completely understand why there are so many species of these microscopic organisms in marine waters. Different species of plankton vary in different seasons due to the changes in physico- chemical nature of water [8]. The phytoplankton community shows high diversity with the seasonal fluctuation, which indicates the diversity in ecological niches $[9,10]$. The role of diversity in ecosystems is pivotal, because species richness can be both a cause and a consequence of primary production. Although there is emerging consensus that diversity enhances productivity and stability in communities of higher organisms. Biodiversity is one of the essential characteristics of ecosystems. In marine environment, the species diversity of phytoplankton is usually high, affected by numerous species of diatoms coming from periphyton and benthic communities. However, such information on phytoplankton of the Palk Bay is very much limited. The aim of the present investigation was to investigate species diversity and abundance of phytoplankton in Muthupettai mangrove environment.

\section{Materials and Methods}

The study was carried out the phytoplankton species diversity and abundance of Muthupettai mangrove region during the year of May 2010 to April 2011. The distributions of phytoplankton were investigated from two different stations. The two stations were (Station-1) Lagoon, (Station-2) Coastal from Muthupettai mangrove regions at Tamil Nadu south east coast of India. Phytoplankton samples were collected at monthly intervals from the waters of the study area. In the different stations by towing a plankton net $(0.35 \mu \mathrm{m}$ mouth diameter) made up

*Corresponding author: Varadharajan D, Faculty of Marine Science, Center of Advanced Study in Marine Biology, Annamalai University, Parangipettai-608 502, Tamil Nadu, India, Tel: 04144-243223; Fax: 04144-243553; E-mail: heartvaradhan@gmail.com

Received June 20, 2015; Accepted August 25, 2015; Published December 15 2015

Citation: Varadharajan D, Soundarapandian P (2015) Biodiversity and Abundance of Phytoplankton from Muthupettai Mangrove Region, South East Coast of India. J Aquac Res Development 6: 383. doi:10.4172/2155-9546.1000383

Copyright: (C) 2015 Varadharajan D, et al. This is an open-access article distributed under the terms of the Creative Commons Attribution License, which permits unrestricted use, distribution, and reproduction in any medium, provided the original author and source are credited. 
Citation: Varadharajan D, Soundarapandian P (2015) Biodiversity and Abundance of Phytoplankton from Muthupettai Mangrove Region, South East Coast of India. J Aquac Res Development 6: 383. doi:10.4172/2155-9546.1000383

Page 2 of 6

of bolting silk (No. 30, mesh size $48 \mu \mathrm{m}$ and No. 10, mesh size $158 \mu \mathrm{m}$, respectively for phytoplankton) for half an hour. These samples were preserved in $4 \%$ neutralized formalin and used for quantitative analysis of phytoplankton. One $\mathrm{ml}$ of this concentrated sample was placed in the Sedgwick rafter cell (no/1) and observed the number of phytoplankton counted under the light microscope at a magnification of 10x, used. Empty frustules were not included in the total counts. Phytoplankton cell identifications were based on standard taxonomic keys $[11,12]$. For the sake of convenience, the phytoplanktons were assigned to some major group's viz. diatoms, dinoflagellates, blue green algae and others for phytoplankton. The phytoplanktons were identified using the standard works of Venkataraman, Cupp, Subrahmanyan $[1,13,14]$. The species evenness, richness, diversity and index were calculated by using computer statistical software package,'ECOSTAT'.

\section{Results}

In the present study, a total of 95 species of phytoplankton were recorded from both the stations, of which, station I recorded 87 species and station II recorded 76 species. The phytoplankton species are maximum were observed in station I and minimum were observed station II (Table 3). The phytoplankton recorded with the present study was belongings to families Coscinodisceae (17) $>$ Ceratiaceae (12) $>$ Chaetoceraceae (11) > Biddulphoidae (9) > Naviculaceae (9) $>$ Triceratiinae (6) $>$ Solenoidae (6) $>$ Fragilariaceae $(5)>$ Dinophyceae (5) $>$ Cyanophyceae (4) $>$ Euodicidae (3) $>$ Eucambiinae (2) > Prorocentraceae (2) > Triadiniaceae (2) > Isthiminae (1) > Gonyaulacaceae (1) (Table 1). The abundance of phytoplankton station I were recorded 86 species the following order of the families: Coscinodisceae (16) >Ceratiaceae (11) > Chaetoceraceae (10) $>$ Biddulphoidae (8) > Naviculaceae $(8)>$ Triceratiinae $(6)>$ Solenoidae (5) $>$ Dinophyceae (5) $>$ Fragilariaceae $(4)>$ Euodicidae (3) $>$ Cyanophyceae (3) > Eucambiinae (2) > Prorocentraceae (2) $>$ Triadiniaceae (2) >Isthiminae (1) > Gonyaulacaceae (1). The abundance of phytoplankton station II were recorded 74 species the following order of the families: Coscinodisceae (14) > Ceratiaceae (9) $>$ Chaetoceraceae (9) > Biddulphoidae (7) $>$ Naviculaceae (7) $>$ Triceratiinae (5) $>$ Solenoidae (5) $>$ Fragilariaceae (5) $>$ Dinophyceae $(4)>$ Cyanophyceae (3) $>$ Euodicidae (2) $>$ Prorocentraceae (2) $>$ Eucambiinae (1) $>$ Isthiminae (1) $>$ Gonyaulacaceae (1) $>$ Triadiniaceae (1) (Table 1).

\begin{tabular}{|c|c|c|c|}
\hline S.No & Species & St I & St I \\
\hline I & Bacillariaphycea(diatoms) & \multicolumn{2}{|c|}{ Cells/1 } \\
\hline & Family : Coscinodisceae & & \\
\hline 1 & Coscinodiscus apiculatus & * & a \\
\hline 2 & Coscinodiscus centralis & * & * \\
\hline 3 & C. centralis & * & * \\
\hline 4 & C.concetricus & * & * \\
\hline 5 & C.granii & a & * \\
\hline 6 & C.gigas & * & * \\
\hline 7 & C.lineatus & * & * \\
\hline 8 & C.radiatus & * & * \\
\hline 9 & C.thori & * & * \\
\hline 10 & Cyclotella meneghiniana & * & a \\
\hline 11 & C. stylorum & * & a \\
\hline 12 & Cyclotella $s p$ & * & * \\
\hline 13 & Diploneis sp. & * & * \\
\hline 14 & Planktoniella sol & * & * \\
\hline 15 & Planktoniella $s p$ & * & * \\
\hline 16 & Skeletonema costatum & * & * \\
\hline 17 & Thalassiosira $s p$ & * & * \\
\hline II & Family: Triceratiinae (Diatoms) & & \\
\hline
\end{tabular}

\begin{tabular}{|c|c|c|c|}
\hline 1 & Ditylum brightwelli & * & * \\
\hline 2 & Ditylum $s p$ & * & * \\
\hline 3 & Triceratium reticuatum & * & * \\
\hline 4 & Triceratium $s p$ & * & * \\
\hline 5 & T.favus & * & * \\
\hline 6 & T.robertsianum & * & a \\
\hline III & Family: Chaetoceraceae (Diatoms) & & \\
\hline 1 & Chaetoceros affinis & * & * \\
\hline 2 & C. curvicetus & * & a \\
\hline 3 & C.decipiens & * & * \\
\hline 4 & C. messanensis & * & * \\
\hline 5 & C.diversus & * & * \\
\hline 6 & C.coarctatus & * & a \\
\hline 7 & C.peruvians & * & * \\
\hline 8 & C.indicus & * & * \\
\hline 9 & C.comosum & * & * \\
\hline 10 & Bacteriostrum furcatum & $a$ & * \\
\hline 11 & Bacteriostrum hyalinum & * & * \\
\hline IV & Family: Biddulphoidae (Diatoms) & & \\
\hline 1 & Biddulphia biddulphia & * & * \\
\hline 2 & B.heteroceros & * & a \\
\hline 3 & B.reticulata & * & * \\
\hline 4 & B.rhombus & * & * \\
\hline 5 & B. sinensis & * & * \\
\hline 6 & B. urita & $a$ & * \\
\hline 7 & B. pulchella & * & a \\
\hline 8 & Odentella sinensis & * & * \\
\hline 9 & O.mobiliensis & * & * \\
\hline $\mathbf{V}$ & Family:Eucambiinae (Diatoms) & & \\
\hline 1 & Eucambia groenlandica & * & a \\
\hline 2 & Eucambia $s p$ & * & * \\
\hline VI & Family: Solenoidae (Diatoms) & & \\
\hline 1 & Leptocylindrus danicus & $a$ & * \\
\hline 2 & Rhizosolenia cylindrus & * & * \\
\hline 3 & R.imbricata & * & * \\
\hline 4 & R. robusta & * & * \\
\hline 5 & R. styliformis & * & a \\
\hline 6 & Bacillaria paradoxa & * & * \\
\hline VII & Family:Isthiminae & & \\
\hline 1 & Isthima nervosa & * & * \\
\hline VIII & Family: Euodicidae (Diatoms) & & \\
\hline 1 & Hemidiscus hardmanianus & * & a \\
\hline 2 & Hemdiscus sinensis & * & * \\
\hline 3 & Hemdiscus sp & * & * \\
\hline \multirow[t]{2}{*}{ IX } & Order:Pennales (Diatoms) & & \\
\hline & Family: Naviculaceae & & \\
\hline 1 & Pleurosigma angulatum & * & * \\
\hline 2 & P.elongatum & * & * \\
\hline 3 & P.depressum & * & a \\
\hline 4 & P.normani & * & * \\
\hline 5 & Nitzshia longissima & * & * \\
\hline 6 & N.seriata & $a$ & * \\
\hline 7 & Pseudo-nitzschia sp. & * & * \\
\hline 8 & Navicula $s p$ & * & * \\
\hline 9 & Stephanophysis palmariana & * & a \\
\hline $\mathbf{x}$ & Family:Fragilariaceae (Diatoms) & & \\
\hline 1 & Thalassionema nitzschioides & * & * \\
\hline 2 & Thalassiothrix fraunfeldi & a & * \\
\hline 3 & Thalassiothrix $s p$ & * & * \\
\hline 4 & Rhabdonema arcuatum & * & a \\
\hline 5 & Achnantia glacialis & * & * \\
\hline
\end{tabular}

( ${ }^{*}$ present of species and ${ }^{a}$ Absent of species)

Table 1: The study period recorded phytoplankton species in Muthupettai mangrove environment during May 2010- April 2011. 
The percentage contribution of phytoplankton families at two different station was in a decrease order as given below: Coscinodisceae $(17.89 \%)>$ Ceratiaceae $(12.63 \%)>$ Chaetoceraceae $(11.57 \%)>$ Biddulphoidae $(9.47 \%)>$ Naviculaceae $(9.47 \%)>$ Triceratiinae $(6.31 \%)$ $>$ Solenoidae $(6.31 \%)>$ Fragilariaceae $(5.26 \%)>$ Dinophyceae $(5.26 \%)$ $>$ Cyanophyceae $(4.21 \%)>$ Euodicidae $(3.15 \%)>$ Eucambiinae $(2.10 \%)$ $>$ Prorocentraceae $(2.10 \%)>$ Triadiniaceae $(2.10 \%)>$ Isthiminae $(1.05 \%)>$ Gonyaulacaceae $(1.05 \%)$ (Table 2). The percentage contribution of phytoplankton families at station I was in a decrease order as given below. Coscinodisceae (18.39\%) >Ceratiaceae $(12.64 \%)>$ Chaetoceraceae $(11.49 \%)>$ Biddulphoidae $(9.19 \%)>$ Naviculaceae $(9.19 \%)>$ Triceratiinae $(6.89 \%)>$ Solenoidae $(5.74 \%)>$ Dinophyceae $(5.74 \%)>$ Fragilariaceae $(4.59 \%)>$ Euodicidae $(3.44 \%)$ $>$ Cyanophyceae $(3.44 \%)>$ Eucambiinae $(2.29 \%)>$ Prorocentraceae $(2.29 \%)>$ Triadiniaceae $(2.29 \%) \quad>$ Isthiminae $(1.149 \%)>$ Gonyaulacaceae (1.149\%) (Table 3). The percentage contribution of phytoplankton families at station II was in a decrease order as given below: Coscinodisceae (18.42) > Ceratiaceae (11.84) $>$ Chaetoceraceae (11.84) > Biddulphoidae (9.21) > Naviculaceae $(9.21)>$ Triceratiinae (6.57) $>$ Solenoidae (6.57) $>$ Fragilariaceae (6.57) $>$ Dinophyceae (5.26) $>$ Cyanophyceae (3.94) > Euodicidae (2.63) > Prorocentraceae (2.63) $>$ Eucambiinae $(1.31)>$ Isthiminae $(1.31)>$ Gonyaulacaceae $(1.31)>$ Triadiniaceae (1.31) (Table 4 ).

The data analysis in Margalef's species richness $\left(d^{\prime}\right)$, ShannonWeiner diversity function $\left(H^{\prime}\right)$, Pielou's evenness $\left(J^{\prime}\right)$ and Simpson's dominance $\left(1-\lambda^{\prime}\right)$ was used to reflect the underlying changes in physical and chemical properties of phytoplankton species. The species richness and diversity of phytoplankton at three sampling stations were determined using Pielous evenness were highest at the station I (0.9215) and lowest at the station II (0.8340). Both Margalef s diversity and richness were highest at the stations I (4.2157 and 5.3810) and lowest at the station II (4.1452 and 5.1073). Both Shannon and Simpson indices were highest at the stations I (4.3261 and 0.9175) and lowest at the station II (4.2958 and 0.9051) (Table 5).

\section{Discussion}

The phytoplanktons contribute approximately $50 \%$ of the global primary production and are the basis of the pelagic food web [15]. They are responsible for most of the transfer of carbon dioxide from the atmosphere to the ocean and even small changes in the

\begin{tabular}{|c|c|c|}
\hline Phytoplankton Family & No of species & Percentage (\%) \\
\hline Coscinodisceae & 17 & 17.89 \\
\hline Triceratiinae & 6 & 6.31 \\
\hline Chaetoceraceae & 11 & 11.57 \\
\hline Biddulphoidae & 9 & 9.47 \\
\hline Eucambiinae & 2 & 2.10 \\
\hline Solenoidae & 6 & 6.31 \\
\hline Isthiminae & 1 & 1.05 \\
\hline Euodicidae & 3 & 3.15 \\
\hline Naviculaceae & 9 & 9.47 \\
\hline Fragilariaceae & 5 & 5.26 \\
\hline Dinophyceae & 5 & 5.26 \\
\hline Ceratiaceae & 12 & 12.63 \\
\hline Gonyaulacaceae & 1 & 1.05 \\
\hline Prorocentraceae & 2 & 2.10 \\
\hline Triadiniaceae & 2 & 2.10 \\
\hline Cyanophyceae & 4 & 4.21 \\
\hline & 95 & 100 \\
\hline
\end{tabular}

Table 2: Total percentage contribution of phytoplankton recorded at two different stations. phytoplankton productivity might affect atmospheric carbon dioxide concentrations [16]. It is play a similar role in the oceans as grass and trees in the terrestrial world, converting sunlight and mineral nutrition to biomass production at the basis of the food web. All other living forms of higher trophic levels are directly or indirectly dependant on phytoplankton for energy supply and therefore, performing vital functions. The phytoplankton diversity is a unimodal function of phytoplankton biomass, with maximum diversity at intermediate levels of phytoplankton biomass and minimum diversity during massive blooms [17]. Ecosystems that undergo significant changes in species composition over time are suitable to analyse the relationship between diversity and production. Changes in species composition and diversity may produce changes in community level parameters, like phytoplankton growth rate and those parameters regulating the photosynthetic response to irradiance and other limiting factors. The phytoplankton diversity responds rapidly to changes in the aquatic ecosystem mostly in relation to levels of nutrient and the environmental variables.

In the present study, a total number of 95 species of phytoplankton were recorded during the present study period from both the stations

\begin{tabular}{|c|c|c|}
\hline Phytoplankton Family & No of species & Percentage (\%) \\
\hline Coscinodisceae & 16 & 18.39 \\
\hline Ceratiaceae & 11 & 12.64 \\
\hline Chaetoceraceae & 10 & 11.49 \\
\hline Biddulphoidae & 8 & 9.19 \\
\hline Naviculaceae & 8 & 9.19 \\
\hline Triceratiinae & 6 & 6.89 \\
\hline Solenoidae & 5 & 5.74 \\
\hline Dinophyceae & 5 & 5.74 \\
\hline Fragilariaceae & 4 & 4.59 \\
\hline Euodicidae & 3 & 3.44 \\
\hline Cyanophyceae & 3 & 3.44 \\
\hline Eucambiinae & 2 & 2.29 \\
\hline Prorocentraceae & 2 & 2.29 \\
\hline Triadiniaceae & 2 & 2.29 \\
\hline Isthiminae & 1 & 1.14 \\
\hline Gonyaulacaceae & 1 & 1.14 \\
\hline & 87 & 100 \\
\hline
\end{tabular}

Table 3: Percentage contribution of phytoplankton at station I.

\begin{tabular}{|c|c|c|}
\hline Phytoplankton Family & No of species & Percentage (\%) \\
\hline Coscinodisceae & 14 & 18.42 \\
\hline Ceratiaceae & 9 & 11.84 \\
\hline Chaetoceraceae & 9 & 11.84 \\
\hline Biddulphoidae & 7 & 9.21 \\
\hline Naviculaceae & 7 & 9.21 \\
\hline Triceratiinae & 5 & 6.57 \\
\hline Solenoidae & 5 & 6.57 \\
\hline Fragilariaceae & 5 & 6.57 \\
\hline Dinophyceae & 4 & 5.26 \\
\hline Cyanophyceae & 3 & 3.94 \\
\hline Euodicidae & 2 & 2.63 \\
\hline Prorocentraceae & 2 & 2.63 \\
\hline Eucambiinae & 1 & 1.31 \\
\hline Isthiminae & 1 & 1.31 \\
\hline Gonyaulacaceae & 1 & 1.31 \\
\hline Triadiniaceae & 1 & 1.31 \\
\hline Total & 76 & 100 \\
\hline
\end{tabular}

Table 4: Percentage contribution of phytoplankton at station II. 


\begin{tabular}{|c|c|c|}
\hline & Station 1 & Station 2 \\
\hline Pielou's evenness J & 0.9215 & 0.8340 \\
\hline Shannon -wienner's diversity(H) & 4.3261 & 4.2958 \\
\hline Margalef's(D)iversity index & 4.2157 & 4.1452 \\
\hline Margalef's(D) Species Richness(SR) & 5.3810 & 5.1073 \\
\hline Simpson's Index(D) & 0.9175 & 0.9051 \\
\hline
\end{tabular}

Table 5: Phytoplankton species evenness, diversity, richness and index.

which include 69; species belongs to diatoms (Bacillariophyceae), 22; species of Dinoflagellates (Dinophyceae) and 4; species of the Blue green algae (Cyanophyceae). The phytoplankton species are maximum were observed in station I and minimum were observed station II (Table 1). The phytoplankton in the mangrove area was characterized by significant species diversity. The dominant groups in the plankton collection were diatoms and dinoflagellates than others. The percentage wise compositions of phytoplankton were dominantly occupied by diatoms than others (Table 3). This study agreed with previous studies such as Rao et al. [18] has been reported only 62 species of phytoplankton from Andhra Pradesh and Sawant et al. [19] has been reported out of 36 species from the west coast of India. However, Rajkumar et al. [20] has been reported 94 species of phytoplankton species belonging to different groups such as Bacillariophyceae (73), Dinophyceae (15), Cyanophyceae (3), Chlorophyceae (2) and Chrysophyceae (1) from Pichavaram mangrove. Perumal et al. [21] has been reported out of 85 species, 58 species of diatoms (Bacillariophyceae), 16 species of dinoflagellates (Dinophyceae), 7 species of blue greens (Cyanophyceae), 3 species of green algae (Chlorophyceae) and silicoflagellates from Kaduviyar estuary. Santhosh Kumar et al. [22] has been reported out of 51 species, 40 species of diatoms (Bacillariophyceae), 8 species of dinoflagellates (Dinophyceae), 1 species of green alga (Chlorophyceae) and 2 species of blue greens (Cyanophyceae) from Aiyyampattinam coasts. Mostly, diatoms were found to be predominant in vegetative water areas, it can be tolerate wide range of hydrographical conditions. It is considered as a euryhaline and eurythermal, which grow under marine conditions. The distribution and abundance of diatoms indicate a favorable environment for active growth and survival of other forms of lives [23]. According to the results diversity of phytoplankton in Muthupettai regions of lagoon (station I) and coastal (station II) is dominated by Diatoms, the family of Coscinodisceae was found to be dominant throughout the study period. Coscinodiscus spp occurred habitually at both stations even as the other genera like Chaetoceros sp, Nitzschia sp, Rhizosolenia sp and Navicula sp were also represented by more number of species at both the stations. Similar observations have been made from different locations of east coast of India [24-26].

Among the diatoms are long and thin plankton that link together in long chains, and they are single-celled algae. It is dominated the plankton community during post- monsoon periods. The abundant diatoms Coscinodiscus apiculatus, Coscinodiscus centralis, Coscinodiscus gigas, Biddulphia biddulphia, Rhizosolenia imbricate, R. robusta, Chaetocerosaffinis, C. messanensis, C. diversus C. coarctatus, Ditylum brightwelli, Planktoniella sp, Skeletonema costatum, Thalassiothrix longissima was observed in the months of January, February and March. Similar findings were earlier reported in different coastal waters by Edward et al. [27] from the Kollidam estuary, Vasantha and Mani $[23,28]$ from the Pitchavaram mangroves. Santhosh Kumar [22] from the Ayyampattinam coast, Senthilkumar and Santhanam [5,29] from the Parangipettai coastal waters.

The maximum diatoms were observed during summer season in the months of April to June. The diatom species which were predominant in the study areas were, Coscinodiscus radiatus, Coscinodiscus centralis,
Coscinodiscus thori, Chaetoceros affinis, Chaetoceros messanensis, Odentellasinensis, Rhizosolenia cylindrus, Rhizosolenia styliformis, Ditylum brightwelli, Triceratium reticulum, Triceratium favus, Hemidiscus hardmanianus, Odentella mobiliensis, Isthima nervosa and Thalassionema nitzschioides. Mostly abundance and dominantly available diatoms Biddulphia biddulphia and followed by Pleurosigma angulatum, Pleurosigma elongatum respectively. Similar findings were observed by Subrahmanyan [14] from the Madras coast, Murugan [8] from the Cuddalore Uppanar backwater. Rajashree et al. [30] from the Gopalpur coast, Santhosh Kumar [22] from the Ayyampattinam coast, Senthilkumar and Santhanam $[5,29]$ from the Parangipettai coastal waters.

The diatoms were observed during premonsoon seasons in the months of July, August and September. There are predominant diatom species occurred in the study areas were, Coscinodiscus thori, Cyclotella sp, Thalassiosira sp, Ditylum sp, Chaetoceros peruvians, C. indicus, Bacteriostrum hyalinum, Biddulphia sinensis, B. pulchella,. Eucambia $s p$, Isthima nervosa, Hemdiscus sp, Nitzshia longissima, Thalassiothrix fraunfeldi and Thalassiothrix sp. The diatom abundance and species count were minimum during the monsoon season in the months of October, November and December, however some species dominantly observed, such as Coscinodiscus centralis, C. gigas, C. radiates, C. thori, Triceratium sp, C. messanensis, C. Peruvians, Bacteriostrum furcatum, Biddulphia reticulate, B. pulchella, O. mobiliensis and Rhizosolenia robusta respectively. Similar observation were made by Raghuprasad [31] from the Palk Bay, Rajashree et al.[30] from the Gopalpur, Rajkumar, Mani and Vasantha $[20,23,28]$ from the Pitchavaram mangroves. The abundance of phytoplankton was minimum was observed during monsoon months, when the water column was remarkably stratified to a large extent because of heavy rainfall, high turbidity caused by runoff, reduced salinity, decreased temperature and $\mathrm{pH}$, cloudy sky and chill conditions. However, the percentage composition and abundance of dominant diatoms varied depending on the nature of substratum, season and distribution of the other co-existing species. Recent studies have revealed that diatoms community structure and diversity are influenced by geographical factors independent of environmental conditions Raghuprasad [31] from the Palk Bay, Vasantha [28] from the Pitchavaram mangroves, Govindasamy [32] from the Coromandel Coast, Rajkumar [20] from the Pichavaram mangrove.

In the present study indicate that the phytoplankton might be possible that once resuspended, benthic diatoms come under the influence of water medium for their survival until they settle to the bottom sediment and find a suitable substratum in the disphotic zone. Senthilkumar, Murugan, Rajkumar $[5,8,20]$ carried out studies on the bloom across the south east coast of India and reported that no equal representation of the species and population density across the collection spots. In the present study a few of the species that represented more in number on the many months and collection spots could not be counted as the maximum in the other months and spots [28]. If these diatoms colonize any substratum, then their growth and community structure is further dependent upon the physico-chemical conditions. The water temperature plays an important role in the periodicity of diatoms. The increased quantity of phytoplankton during summer months can be due to higher concentration of free carbondioxide present in the water which may influence the growth of diatoms, the important of silica, nitrate and phosphate as single factor and as factor complex in the periodicity of diatoms. Vasantha, Rajkumar [20,28] has been reported that the higher concentration of silica was associated with both the minimum and maximum of phytoplankton, mainly composed of Bacillariophyceae. 
The dinoflagellates have two flagella and they come in all shapes and sizes. It is one of the dominant protist group and greatest diversity in tropical oceanic regions. In the present study dinoflagellates species contributed significantly to phytoplankton than diatom species. The maximum diatom species was observed in the study areas were Dinophysis sp, Ceratium sp, peridinium sp followed by the Prorocentrum sp. The Dinophysis caudate, D. punctata and Ceratium furca, Ceratium inflatum, peridinium oceanicum, Prorocentrum reticulatum there are widely distributed in both stations. It may be occurrences of the second largest group followed by blue-greens and greens. Their abundance varies with the seasons and is usually greatest during the summer (April to June) and premonsoon (July-October) and minimum was observed postmonsoon (January-March) and monsoon (OctoberDecember) seasons. The maximum species abundance was recorded from the lagoon areas (station 1) might have been favored by the high nutrient levels recorded at this station when compared to the coastal waters (station 2). Similar observation were made by Raghuprasad [31] from the Palk Bay, Rajashree et al. [30] from the Gopalpur, Mani, Vasantha $[23,28]$ from the Pitchavaram mangroves, Govindasamy [32] from the Coromandel Coast. Rajkumar [20] from the Pichavaram mangrove. The majority of dry season species cannot survive in these low salinities and migrate to higher salinity areas offshore. Srilatha et al. [33] has been observed most upon the species cannot survive in low salinity period. However, during the rainy season, the increased flow of freshwater results in the appearance of freshwater species.

The blue green algae were found to grow in summer season, but some of them also occurred in premonsoon seasons. The Tricodesmium sp growth was most abundant in the environment. In the present study has indicated the high diversity and low production of phytoplankton in coastal waters when compared lagoon area. The dinoflagellates usually do better in coastal environment with lower nutrient concentrations because there is less of a competition with diatoms. There was a strong correlation of high dinoflagellate abundance and low nutrient concentrations found in coastal environment. In lagoon areas high turbidity, large salinity fluctuations and a generally small ratio of open waters way to mangrove forest area contribute to the low light levels and shading that limit productivity of the phytoplankton. Since the nutrients, such as nitrogen, phosphorus input from nearby human population centers and naturally occurring substances may also regulate the phytoplankton growth. Selvam et al. [34] has been reported that the primary production to be four times higher in mangrove waters than in adjacent marine waters in east coast of India. It has been addressed to determine the species composition and diversity of microalgae in these sampling stations.

In the present study, maximum population density was recorded summer season during the months of April and May at both station 1 (59,000 cells 1-1) and station 2 (41,000 cells 1-1), the reason of decreased the nutrient concentrations during summer season. The density gradually declined during June and premonsoon period and minimum value were observed during the months of November and December. This term agreed with the previously reported that the maximum density of phytoplankton during the summer season, Raghuprasad [31] from the Palk Bay, Rajashree et al. [30] from the Gopalpur, Mani, Vasantha $[23,28]$ from the Pitchavaram mangroves, Govindasamy [32] from the Coromandel Coast. Rajkumar [20] from the Pichavaram mangrove, Sarojini [2] from the Andaman and Nicobar Islands.

In the present investigation the habitually availability of biolimiting elements such as nitrogen, phosphorous and inorganic phosphate is an important factor affecting phytoplankton production. Energetic growth of phytoplankton reduces the levels of micronutrients such as nitrates, phosphates and silicates in the surface layers restricting the primary production. The important nutrients are replenished mostly by way of degeneration of dead ones and mixing of nutrient rich bottom water by upwelling and turbulence. This again to a great extent is governed by local climatic conditions and geography [20,24,27,28]. There it is extremely important from the standpoint of monitoring water quality since they are the first group to respond to changes in nutrient conditions in an ecosystem. The temperature seemed to be primarily responsible for the shifts in phytoplankton assemblages, additional factors like salinity, $\mathrm{pH}$, dissolved oxygen and nutrient availability also played significant role in the spatial and temporal distribution of phytoplankton populations. During the study period as nutrient availability varied due to climatic and anthropogenic factors, species assemblages and phytoplankton abundance fluctuated as well. However, the increase in their population was mainly influenced by physical factors rather than chemical factors. Velocity of flow, water level and wind are the main physical factors influencing the population of phytoplankton. In the present study is now a good evidence of ecological impacts of recent climate change on ecosystems. A major challenge in climate change research on phytoplankton succession is to understand the multiple factors, which drive ecological changes in phytoplankton communities. Increasing sea surface temperature is likely to alter phytoplankton bloom dynamic and the changes in water transparency and turbidity, nutrient availability and size also reorganize phytoplankton community structure affecting species diversity. It is commonly known that nutrient regions are characterised by maximum numbers of species and present studies confirm a positive relationship between physico-chemical parameters and species diversity across marine ecosystems.

Here it would be concluded that the abundance and productivity of phytoplankton is determined by a combination of environmental conditions and physiological features of different phytoplankton species and by ecological interactions between different trophic levels. The biomass distribution and species compositions of phytoplankton have important effects on carbon fixation rates and on transfer of energy in food webs. Considerable variability exists in physiological and morphological adaptations of the phytoplankton species which act to maximise the utilisation of light and nutrients and minimise the effect of grazing. Given that sufficient light is available, phytoplankton organisms have a high potential for growth in nutrient-rich environments and can develop dense blooms with possible deleterious effects on fish, benthic fauna and human health. Phytoplanktons are therefore key-organisms in programs which monitor the environmental status of the marine environment. The coastal ecosystems are now highly disturbed and very much threatened, encountering problems like pollution, siltation, and erosion, flooding saltwater intrusion, storm surges and other activities due to ever expanding human settlements.

\section{References}

1. Venkataraman GA (1939) Systematic account of some South Indian diatoms Proc Indian Acad Sci 10: 293-368.

2. Sarojini Y, Sarma NS (2001) Phytoplankton distribution in the sea around Andaman and Nicobar Islands at the onset of North East Monsoon. Sea Weed Res Util 23: 133-141.

3. Senthilkumar S, Santhanam P, Perumal P (2002) Diversity of phytoplankton in Vellar estuary, southeast coast of India. In: Proc. 5th Indian Fisheries Forum (Eds) S Ayyappan, JK Jena and M Mohan Joseph. Published by AFSIB Mangalore and AeA, Bhubanewar, India. 245- 248.

4. Geetha Madhav V, Kondalarao B (2004) Distribution of phytoplankton in the coastal waters of east coast of India. Ind J Mar Sci 33: 262-268. 
Citation: Varadharajan D, Soundarapandian P (2015) Biodiversity and Abundance of Phytoplankton from Muthupettai Mangrove Region, South East Coast of India. J Aquac Res Development 6: 383. doi:10.4172/2155-9546.1000383

5. Senthilkumar R, Sivakumar K (2008) Studies on phytoplankton diversity in response to abiotic factors in Veeranam lake in the Cuddalore district of Tamil Nadu. J Environ Biol 29: 747-752.

6. Lalli CM, Parsons TR (1997) Biological Oceanography an Introduction (2ndedn), Elseveir, Oxford.

7. Miller C (2004) Biological oceanography. Blackwell Publishing 1-391.

8. Murugan A, Ayyakannu K (1991) Ecology of Uppanar backwater, Cuddalore: I. Physico-chemical parameters. Natl Inst Oceanography 24: 31-38.

9. Diehl S (2007) Paradoxes of enrichment: Effects of increased light versus nutrient supply on pelagic producer-grazer systems. Am Nat 169: E173- E191.

10. Nowrouzi S, Valavi H (2011) Effects of environmental factors on phytoplankton abundance and diversity in Kaftar Lake. J Fish Aquat Sci 6: 130-140.

11. Botes L (2003) Phytoplankton identification catalogue- Saldanha Bay, South Africa, April 2001, Globallast Monograph Series No.7, IMO London.

12. Verlencar XN, Desai S (2004) Phytoplankton Identification Manual (1stedn), National Institute of Oceanography, Dona Paula, Goa, India.

13. Cupp EE (1943) Marine plankton diatoms of the west coast of North America. Bull Scripps Inst Oceanogr 5: 1-237.

14. Subrahmanyan R (1946) The diatoms of the Madras coast. Proc. Indian Acad Sci 24: 85-197.

15. Waniek JJ, Holliday NP (2006) Large scale physical control on phytoplankton growth in the Irminger Sea, Part II: Model study of the physical and meteorological preconditioning. J Mar Sys 59: 219-237.

16. Dongyan L, Jun S, Zhe L (2004) The effects of spring-neap tide on the phytoplankton community development in the Jiaozhou bay, China. Acta Oceanologica Sinica 23: 687-697.

17. Perumal P (1993) The influence of meteorological phenomena on the ecosystems of a tropical region, southeast coast of India. A case study. Ciencieas Marinas 19: 343-351.

18. Rao MU, Sarojini Y (1992) Composition, abundance and vertical distribution of phytoplankton and fungi off Krishna and Godavari river mouths, east coast of India. Indian J Mar Sci 21: 128-132.

19. Sawant S, Madhupratap M (1996) Seasonality and composition of phytoplankton in the Arabian Sea. Curr Sci 71: 869-873.

20. Rajkumar M, Perumal P, Ashok Prabu V, Vengadesh Perumal N, Thilla Rajasekar K (2009) Phytoplankton diversity in Pichavaram mangrove waters from south-east coast of India. Journal of Environmental Biology 30: 489-498.
21. Perumal NV, Rajkumar M, Perumal P, Thillai Rajasekar K (2009) Seasonal variations of plankton diversity in the Kaduviyar estuary, Nagapattinam, southeast coast of India. Journal of Environmental Biology 30: 1035-1046.

22. Kumar S, Perumal (2012) Studies on phytoplankton characteristics in Ayyampattinam coast, India. J Environ Biol 33: 585-589.

23. Mani P (1994) Phytoplankton in pitcharavarm mangroves, eastcoast of India Indian J Mar Sci 23: 22-26.

24. Sourina A, Richard M (1976) Phytoplankton and its contribution to primary production in two coral reef areas of French Polynesia. J Exp Mar Biol Ecol 21: $129-140$.

25. Pena MA, Lewis MR, Harrison WG (1990) Primary productivity and size structure of Phytoplankton biomass on a transect of the equator at $135^{\circ} \mathrm{W}$ in the Pacific Ocean. Deep- Sea Res 37: 295-315.

26. Gowda G, Gupta TRC, Mani P (1992). Natural phytoplankton communities in Pichavaram mangroves. Indian J Mar Sci 21: 278-280.

27. Edward JKP, Ayyakkannu K (1991) Studies on the ecology of plankton community of Kollidam estuary, southeast coast of India. 1. Phytoplankton. Natl Inst Oceanogr 24: 89-97.

28. Vasantha K (1989) Studies on hydrobiology and decomposition of macrophytes in Porto Novo marine environment (Southeast coast of India), Ph.D., Thesis, Annamalai University, India, 252

29. Santhanam P, Perumal P (2003) Diversity of zooplankton in Parangipetta coastal waters, southeast coast of India. J Mar Biol Ass India 45: 144-151.

30. Rajashree G, Panigrahy RC (1996) Ecology of phytoplankton in coastal waters off Gopalpur, east coast of India. Ind J Mar Sci 25: 13-18.

31. Raghuprasad R (1958) Plankton calendars of the inshore waters at Mandapam, with a note on the productivity of the area. Indian J Fish 5: 170-188.

32. Govindasamy C (1992) Coromandel Coast of India - A study on hydrobiology and heavy metals, Ph.D., Thesis, Annamalai University, India, 119.

33. Srilatha G, Thilagavathi B, Varadharajan D (2012) Studies on the physicochemical status of muthupettai mangrove, south east coast of India. Advan Appl Sci Res 3: 201-207.

34. Selvam V, Azariah J, Azariah H (1992) Diurnal variation in physico-chemica properties and primary production in the interconnected marine, mangrove and freshwater biotopes of Kakinda coast, Andhra Pradesh, India. Hydrobiol 247 181-186. 